\title{
Analisis Preferensi Konsumen dan Proksimat Cookies Bebas Gluten Berbahan Baku Tepung Ubi Kayu (Manihot utilissima) Tinggi Protein
}

\section{Analysis on Preferences of Consumers and Proximates of Gluten Free Cookies with High Protein Cassava Flour}

\author{
Zukryandry $^{*}$, Beni Hidayat ${ }^{1}$, dan Dayang Berliana ${ }^{2}$ \\ ${ }^{1}$ Jurusan Teknologi Pertanian Program Studi Teknologi Pangan Politeknik Negeri Lampung \\ Jl. Soekarno-Hatta No. 10 Rajabasa, Bandar Lampung, 35144 \\ 2 Jurusan Ekonomi dan Bisnis Program Studi Agribisnis Pangan Politeknik Negeri Lampung \\ Jl. Soekarno-Hatta No. 10 Rajabasa, Bandar Lampung, 35144 \\ *E-mail : zukryandry@polinela.ac.id
}

\begin{abstract}
The development of cookies products using high-protein cassava flour has never been conducted by a small industry. Industry players do not have information on consumer responses to cookies made from high-protein cassava flour with the addition of palm sugar. This study aimed to analyze consumer preferences and proximate analysis of cookie products with various levels of palm sugar additions. This research used cross section data where the sampling was carried out by accidental sampling as many as 25 panelists. The method used was a multi-attribute analysis of fishbein, and proximate analysis was conducted on best products. The results showed that the panelists preferred F1 cookies products (added by $25 \%$ palm sugar) with positive values, and overall this means that consumers' attitudes towards F1 cookies products were considered good. The addition of palm sugar as much as $25 \%$ produces cookies with a moisture content $3.39 \%$, protein content $4.11 \%$, fat content $27.6 \%$, fiber content $9.67 \%$, ash content $1.32 \%$ and carbohydrate $64.56 \%$
\end{abstract}

Keywords: Cookies, Preferences, Fishbein, Proximate

Disubmit : 14 Agustus 2019, Diterima: 10 September 2019, Disetujui : 10 Oktober 2019

\section{PENDAHULUAN}

Tepung terigu banyak digunakan sebagai bahan baku berbagai macam produk olahan seperti makanan ringan, mie, roti, kue, bakso, dan berbagai aneka produk makanan kecil. Berdasarkan data APTINDO (2016) peningkatan konsumsi tepung terigu pada tahun 2013 sebesar 5142000 MT meningkat pada tahun 2015 sebesar 5483000 MT atau mengalami peningkatan sebesar 6.63\%. Konsumsi terigu berasal dari gandum yang meningkat tidak diikuti dengan peningkatan produksi, sehingga untuk memenuhi kebutuhan bahan baku dilakukan impor. Berdasarkan data BPS (2018) impor terigu tahun 2013 sebesar 6 720499 MT meningkat pada tahun 2017 sebesar 11225582 atau mengalami pertumbuhan sebesar 40.13\%.

Ketergantungan pada impor gandum harus dikurangi, salah satu solusi yang dapat diterapkan yaitu melakukan substitusi tepung terigu dengan tepung lokal. Indonesia memiliki beberapa tepung yang dapat mensubstitusi tepung terigu dari beberapa komoditas lokal seperti ubi kayu dan ubi jalar. Berdasarkan data BPS (2018) Lampung merupakan provinsi yang memiliki produksi ubi kayu tertinggi di Indonesia yaitu sebesar 7387084 ton. Tepung ubi kayu dapat dikembangkan sebagai komoditas bahan pangan unggulan 
Provinsi Lampung. Tepung ubi kayu tinggi protein merupakan tepung yang ditingkatkan kandungan proteinnya melalui proses fermentasi dengan menggunakan khamir Saccharomyces cerevisiae. Kandungan protein pada tepung ini $>6 \%$, peningkatan protein ini disebabkan oleh khamir itu sendiri.Tepung ubi kayu tinggi protein dapat dibuat dari ubi kayu konsumsi maupun ubi kayu tinggi HCN ( $>500$ ppm). Keuntungan penggunaan ubi kayu tinggi HCN yaitu dapat meningkatkan nilai tambah ubi kayu tinggi HCN yang umumnya hanya digunakan dalam produksi tapioka. Pembuatan tepung tinggi protein dapat memperluas penggunaan tepung ubi kayu sebagai bahan pangan (Hidayat, et al., 2018).

Perkembangan produk makanan khususnya makanan ringan seperti cookies, biskuit, wafer, food bar semakin banyak variasinya. Konsumsi rata-rata kue kering termasuk cukup di Indonesia, tahun 2013-2017 memiliki perkembangan konsumsi rata-rata sekitar $33.31 \%$ lebih tinggi dibandingkan rata-rata konsumsi kue basah 23,38 \% (Kementerian Pertanian, 2018). Salah satu makanan ringan yang sudah dikenal oleh masyarakat adalah cookies. Cookies atau kue kering juga sering menjadi simbol dalam perayaan-perayaan khusus, misalnya lebaran, natal, dan lain-lain (Hanifa, et al., 2013).

Pengembangan produk cookies menggunakan tepung ubi kayu tinggi protein belum pernah dilakukan oleh industri kecil. Pelaku industri belum mempunyai informasi tentang respon konsumen terhadap makanan olahan yang menggunakan tepung ubi kayu tinggi protein, oleh karena itu diperlukan penelitian tentang preferensi konsumen terhadap produk cookies berbahan baku tepung ubi kayu tinggi protein dengan penambahan gula palm sebanyak 25\% (F1), 30\% (F2), dan 35\% (F3). Penelitian ini bertujuan menganalisis preferensi konsumen terhadap cookies dengan berbagai tingkatan penambahan gula palm sebanyak 25\% (F1), 30\% (F2), dan 35\% (F3) dan cookies terbaik selanjutnya dilakukan analisis proksimat.

\section{METODE PENELITIAN}

Penelitian dilakukan di Politeknik Negeri Lampung. Penelitian dilaksanakan pada Bulan AgustusSeptember 2019. Penelitian ini menggunakan data primer melalui wawancara kepada panelis dengan panduan kuesioner. Jenis data yang digunakan adalah data cross section. Pengambilan sampel dengan accidental sampling, yaitu metode yang digunakan dengan menentukan siapa saja yang masuk anggota sampel penelitian yang dapat memberikan informasi yang diinginkan sesuai dengan permasalahan penelitian sebanyak 25 orang.

\section{Model Sikap Fishbein}

Model analisis fishbein yaitu suatu model yang menunjukkan sikap konsumen terhadap suatu objek tertentu berdasarkan pada perangkat kepercayaan yang diringkas mengenai atribut objek yang bersangkutan yang diberi bobot oleh evaluasi terhadap atribut. Atribut yang digunakan dalam penelitian ini adalah warna, aroma, tekstur, rasa, harga dan kemasan. Variabel sikap yang terdapat didalam analisis fishbein terbagi menjadi dua yaitu: (1) Variabel kepercayaan, merupakan tanggapan oleh konsumen terhadap atribut produk cookies dan (2) Variabel evaluasi, merupakan tanggapan oleh konsumen terhadap produk cookies secara menyeluruh. Secara simbolis, formulasi model fishbein dapat dirumuskan sebagai berikut :

$$
A o=\sum_{i=1}^{n} \text { bi. ei }
$$

Keterangan :

Ao $\quad$ : Sikap terhadap objek 
Jurnal Penelitian Pertanian Terapan

bi $\quad$ : Tingkat kepercayaan bahwa objek memiliki atribut i

ei : Evaluasi kepentingan terhadap atribut $\mathrm{i}$

$\mathrm{n} \quad$ : Jumlah atribut yang dimiliki oleh objek

Langkah pertama yang dilakukan dalam menghitung sikap adalah menentukan atribut objek. Atribut yang digunakan dalam analisis ini berjumlah enam atribut yaitu warna, aroma, tekstur, rasa, harga dan kemasan. Atribut yang digunakan untuk komponen (bi) harus sama dengan atribut yang digunakan untuk komponen (ei). Langkah kedua adalah menentukan pengukuran terhadap komponen kepercayaan (bi) dan komponen evaluasi (ei). Komponen (bi) menggambarkan seberapa kuat konsumen percaya bahwa objek memiliki atribut yang diberikan. Indikator skala ukuran kuantitatif untuk tingkat kepentingan menurut persepsi konsumen dan kinerja secara nyata dinyatakan dalam skala likert. Skala likert merupakan skala pengukuran ordinal. Hasil pengukurannya hanya dapat dibuat peringkat tanpa diketahui besar selisih antara satu tanggapan dengan tanggapan lain. Kekuatan kepercayaan biasanya diukur pada skala likert dengan 5 (lima) angka dimulai dari sangat baik (5), baik (4), biasa saja (3), buruk (2), dan sangat buruk (1).

Langkah selanjutnya adalah menghitung rata-rata nilai (ei) dan (bi) setiap atribut, kemudian setiap skor kepercayaan (bi) harus dikalikan dengan skor evaluasi (ei) yang sesuai atributnya. Seluruh hasil perkalian harus dijumlahkan sehingga dari hasil tabulasi dapat diketahui sikap konsumen (Ao) terhadap produk dengan membandingkannya menggunakan skala interval dengan rumus sebagai berikut:

$$
\text { Skala Interval }=\frac{m-n}{b}
$$

Keterangan :

$\mathrm{m}=$ Skor tertinggi yang mungkin terjadi

$\mathrm{n}=$ Skor terendah yang mungkin terjadi

$\mathrm{b}=$ Jumlah skala penilaian yang terbentuk

Nilai kepentingan (ei) dan nilai kinerja (bi) responden terhadap atribut cookies dikategorikan pada rentang skala interval yang dapat dilihat pada Tabel 1.

Tabel 1 Kategori Tingkat Kepentingan dan Tingkat Kepercayaan

\begin{tabular}{llll}
\hline Tingkat Kepentingan & Nilai & Tingkat Kepercayaan & Nilai \\
\hline Sangat Tidak Penting & $1.0 \leq \mathrm{ei} \leq 1.8$ & Sangat Buruk & $1.0 \leq \mathrm{ei} \leq 1.8$ \\
Tidak Penting & $1.8<\mathrm{ei} \leq 2.6$ & Buruk & $1.8<\mathrm{ei} \leq 2.6$ \\
Biasa & $2.6<\mathrm{ei} \leq 3.4$ & Biasa & $2.6<\mathrm{ei} \leq 3.4$ \\
Penting & $3.4<\mathrm{ei} \leq 4.2$ & Baik & $3.4<\mathrm{ei} \leq 4.2$ \\
Sangat Penting & $4.2<\mathrm{ei} \leq 5.0$ & Sangat Baik & $4.2<\mathrm{ei} \leq 5.0$ \\
\hline
\end{tabular}

Hasil penilaian sikap responden terhadap atribut (ei.bi) secara keseluruhan terhadap atribut cookies berbahan tepung ubi kayu tinggi protein dengan penambahan gula palm sebanyak 25\% (F1), 30\% (F2), dan $35 \%$ (F3) akan diinterpretasikan ke dalam lima kategori, yaitu sangat positif, positif, netral, negatif dan sangat negatif. Besarnya range untuk kategori sikap yaitu:

$$
\frac{[(5 \times 5)-(1 \times 1)]}{5}=4.8
$$


Penilaian sikap responden terhadap cookies berbahan tepung ubi kayu tinggi protein dengan penambahan gula palm sebanyak 25\% (F1), 30\% (F2), dan 35\% (F3) secara keseluruhan dikategorikan pada rentang skala interval yang dapat dilihat pada Tabel 2.

Tabel 2 Kategori Nilai Sikap terhadap Atribut Secara Keseluruhan

\begin{tabular}{ll}
\multicolumn{1}{c}{ Tingkat Kepentingan } & Nilai \\
\hline Sangat Negatif & $1.0 \leq \mathrm{ei} \leq 1.8$ \\
Negatif & $1.8<\mathrm{ei} \leq 2.6$ \\
Netral & $2.6<\mathrm{ei} \leq 3.4$ \\
Positif & $3.4<\mathrm{ei} \leq 4.2$ \\
Sangat Positif & $4.2<\mathrm{ei} \leq 5.0$ \\
\hline
\end{tabular}

\section{Analisis Proksimat}

Analisis proksimat produk cookies berbahan baku tepung ubi kayu tinggi protein yaitu analisis kadar air dengan menggunakan metode Thermogravimetri (AOAC, 2005), analisis kadar abu dengan menggunakan metode Thermogravimetri (AOAC, 2005), analisis kadar protein (AOAC, 2005), analisis kadar lemak (AOAC, 2005) dan analisis kadar serat kasar.

\section{HASIL DAN PEMBAHASAN}

\section{Analisis Tingkat Kepentingan (Evaluation)}

Perilaku atau tindakan konsumen terhadap suatu produk dipengaruhi oleh sikap konsumen. Sebelum melakukan uji sensori terhadap cookies berbahan tepung ubi kayu tinggi protein dengan penambahan gula palm sebanyak 25\% (F1), 30\% (F2), dan 35\% (F3), panelis diminta untuk menyatakan pendapatnya terhadap enam buah atribut dari produk cookies. Penilaian terhadap sikap panelis ditentukan oleh evaluasi komponen ei dari sikap panelis. Hasil evaluasi tingkat kepentingan setiap atribut pada produk cookies ditunjukkan pada Tabel 3.

Tabel 3. Frekuensi dan skor atribut tingkat kepentingan (ei) cookies

\begin{tabular}{llllllll}
\hline \multirow{2}{*}{ No } & Atribut & \multicolumn{4}{c}{ Frekuensi Pada Setiap Nilai } & \multicolumn{2}{c}{ Skor Evaluasi (ei) } \\
\cline { 3 - 7 } & & $\mathbf{1}$ & $\mathbf{2}$ & $\mathbf{3}$ & $\mathbf{4}$ & $\mathbf{5}$ & 3,64 \\
\hline 1 & Warna & 1 & 4 & 5 & 8 & 7 & 4,12 \\
2 & Aroma & 0 & 3 & 5 & 3 & 14 & 4,24 \\
3 & Rasa & 0 & 3 & 1 & 8 & 13 & 4,08 \\
4 & Tekstur & 0 & 4 & 3 & 5 & 13 & 4,16 \\
5 & Harga & 0 & 3 & 2 & 8 & 12 & 3,96 \\
6 & Kemasan & 0 & 3 & 7 & 3 & 12 & 4,03 \\
\hline \multicolumn{2}{l}{ Skor Rata-rata Evaluasi Produk }
\end{tabular}

Sumber : Data Primer, 2019 (diolah)

Berdasarkan Tabel 3 menunjukkan atribut rasa memiliki skor ei tertinggi sebesar 4.24. Rasa pada produk merupakan atribut terpenting dan diinginkan konsumen. Atribut rasa dapat meningkatkan selera konsumen. Rasa yang enak menentukan penilaian suka dan tidak suka terhadap produk. Sumarwan, et al (2013), Nafisah (2013), dan Yulya (2017)rasa yang enak mengakibatkan konsumen berminat untuk melakukan pembelian. Atribut kedua yang dianggap paling penting adalah atribut aroma cookies sebesar 
4.12. Konsumen menginginkan aroma cookies yang khas. Aroma yang khas dapat membangkitkan selera konsumen. sehingga akan menentukan penilaian suka atau tidak sukanya konsumen. Jika aroma cookies khas, konsumen berminat untuk melakukan pembelian ulang.

Atribut ketiga paling penting menurut konsumen adalah harga sebesar 4,16. Harga menjadi pertimbangan konsumen sebelum membeli produk. Hasil evaluasi menunjukkan bahwa harga juga penting karena berhubungan dengan tingkat pendapatan dan daya beli konsumen. Menurut Hartono, et al (2012) Penetapan harga oleh penjual akan berpengaruh terhadap perilaku pembelian konsumen, sebab harga yang dapat dijangkau oleh konsumen akan cenderung membuat konsumen melakukan pembelian terhadap produk tersebut.

Posisi keempat diduduki oleh atribut tekstur sebesar 4,08. Tekstur cookies menjadi salah satu pertimbangan utama konsumen dalam membeli produk. Konsumen cenderung melakukan pembelian pada cookies yang lembut, padat, dan tahan lama. Sementara itu, atribut yang memperoleh skor kepentingan terendah adalah kemasan sebesar 3,96 dan warna sebesar 3,64. Hasil skor rata-rata evaluasi produk cookies pada konsumen sebesar 4.03, yang menunjukkan bahwa evaluasi konsumen terhadap atribut-atribut produk tersebut berada pada kategori penting dalam proses keputusan pembelian.

\section{Analisis Tingkat Kepercayaan (Believe)}

Komponen keyakinan dalam model fishbein adalah tingkat kepercayaan bahwa obyek sikap memiliki atribut tertentu (Susanti, 2008). Komponen pelaksanaan menunjukkan penilaian konsumen terhadap pelaksanaan atribut produk produk cookies berbahan baku tepung ubi kayu tinggi protein dengan penambahan gula palm sebanyak 25\% (F1), 30\% (F2), dan 35\% (F3). Kategori pelaksanaan terbagi dalam lima kelas, mulai dari 1-1.8 = sangat tidak baik, 1.9-2.6 = tidak baik, 2.6-3.4 = biasa, 3.5-4.2 = baik, 4.3-5 = sangat baik. Hasil nilai kepercayaan atribut produk cookies berbahan baku tepung ubi kayu tinggi protein dengan penambahan gula palm sebanyak 25\% (F1), 30\% (F2), dan 35\% (F3) dapat dilihat pada Tabel 4.

Berdasarkan hasil Tabel 4 cookies F1 (20.4) memperoleh total skor kepercayaan yang lebih tinggi dibandingkan cookies F2 (18.32), dan cookies F3 (17.2). Ketiga cookies memiliki keunggulan tersendiri pada atributnya. Berdasarkan hasil skor kepercayaan pada Tabel 4, cookies F1 memiliki 3 keunggulan atribut dengan kategori baik dan 2 keunggulan dengan kategori biasa dibandingkan dengan cookies $\mathrm{F} 2$ dan cookies F3. Tabel 4 menunjukkan bahawa cookies F1 memiliki keunggulan pada atribut rasa (3.36), aroma (3.52), tekstur (3.52). Kepercayaan atribut kategori pelaksanaan biasa dan memperoleh skor kepercayaan atribut lebih rendah yaitu warna (3.36), dan harga (3.32) kemasan (3.08).

Tabel 4 Nilai Kepercayaan (bi) dan Kategori Tingkat Pelaksanaan Atribut Cookies

\begin{tabular}{lcccccc}
\hline \multirow{2}{*}{ Atribut } & \multicolumn{2}{c}{ F1 } & \multicolumn{2}{c}{ F2 } & F3 \\
\cline { 2 - 7 } & Tingkat & $\begin{array}{c}\text { Kategori } \\
\text { Pelaksanaan }\end{array}$ & $\begin{array}{c}\text { Tingkat } \\
\text { Kepercayaan }\end{array}$ & $\begin{array}{c}\text { Kategori } \\
\text { Pelaksanaan }\end{array}$ & $\begin{array}{c}\text { Tingkat } \\
\text { Kepercayaan }\end{array}$ & $\begin{array}{c}\text { Kategori } \\
\text { Pelaksanaan }\end{array}$ \\
\hline Warna & 3.36 & Biasa & 3.32 & Biasa & 3.28 & Biasa \\
Aroma & 3.52 & Baik & 2.68 & Biasa & 2.44 & tidak baik \\
Rasa & 3.6 & Baik & 3.12 & Biasa & 2.96 & Biasa \\
Tekstur & 3.52 & Baik & 3.2 & Biasa & 3.08 & Biasa \\
Harga & 3.32 & Biasa & 2.8 & Biasa & 2.52 & tidak baik \\
Kemasan & 3.08 & Biasa & 3.2 & Biasa & 2.92 & Biasa \\
\hline Total & 20.4 & & 18.32 & & & 17.2 \\
\hline
\end{tabular}

Sumber : Data Primer, 2019 (diolah)

Tabel 4 menunjukkan atribut cookies F2 memiliki keunggulan pada kemasan dengan score (3.2) kategori biasa dibandingkan dengan cookies F1 dan cookies F3. Atribut cookies F2 pada warna (3.32), aroma (2.68), rasa (3.12), tekstur (3.2), harga (3.32), dan kemasan (3.08) memiliki skor yang unggul dengan kategori penilaian biasa dibandingkan dengan cookies F3. Atribut cookies F3 secara keseluruhan nilai kepercayaannya paling rendah dibandingkan cookies F1 dan cookies F2. Cookies F3 memiliki kategori biasa 
yaitu warna (3.28), rasa (2.96), tekstur (3.08), dan kemasan (2.92). Cookies F3 memiliki kategori tidak baik pada atribut aroma $(2,44)$ dan harga $(2.52)$.

\section{Sikap Konsumen terhadap Atribut Cookies}

Nilai sikap konsumen untuk cookies berbahan baku tepung ubi kayu tinggi protein dengan penambahan gula palm sebanyak 25\% (F1), 30\% (F2), dan 35\% (F3) didapatkan setelah mengalikan skor evaluasi kepentingan (ei) masing-masing atribut dengan skor kepercayaan (bi). Apabila nilai sikap untuk masing-masing atribut dijumlahkan maka akan didapat nilai sikap secara keseluruhan untuk cookies (Ao). Hasil analisis sikap responden (ei.bi) dan total nilai sikap (Ao) terhadap atribut cookies (F1), cookies (F2), dan cookies (F3) secara keseluruhan dapat dilihat pada Tabel 5. Penentuan interpretasi sikap terhadap cookies dibagi menjadi lima kategori, mulai dari 1-5.8 = sangat negatif, 5.9-10.6 = negatif, 10.7-15.4 = netral, $15.5-20.2=$ positif dan 20.3-25 = sangat positif.

Tabel 5. Sikap Konsumen Terhadap Atribut Cookies

\begin{tabular}{lccccccc}
\hline \multirow{2}{*}{ Atribut } & \multirow{2}{*}{ Kepentingan (ei) } & \multicolumn{2}{c}{ F1 } & \multicolumn{2}{c}{ F2 } & \multicolumn{2}{c}{ F3 } \\
\cline { 3 - 8 } & & Belief (bi) & Sikap (Ao) (ei.bi) & Belief & Sikap (Ao) (ei.bi) & Belief & Sikap (Ao) (ei.bi) \\
\hline Warna & 3.64 & 3.36 & 12.23 & 3.32 & 12.08 & 3.28 & 11.94 \\
Aroma & 4.12 & 3.52 & 14.50 & 2.68 & 11.04 & 2.44 & 10.05 \\
Rasa & 4.24 & 3.60 & 15.26 & 3.12 & 13.23 & 2.96 & 12.55 \\
Tekstur & 4.08 & 3.52 & 14.36 & 3.20 & 13.06 & 3.08 & 12.57 \\
Harga & 4.16 & 3.32 & 13.81 & 2.80 & 11.65 & 2.52 & 10.48 \\
Kemasan & 3.96 & 3.08 & 12.20 & 3.20 & 12.67 & 2.92 & 11.56 \\
\hline Total & & 82.37 & & 73.73 & & 69.16 \\
\hline
\end{tabular}

Sumber : Data Primer, 2019 (diolah)

Berdasarkan Tabel 5 cookies F1 memiliki sikap positif atau baik adalah rasa (15.26). Hal ini menunjukkan rasa merupakan atribut yang disukai oleh responden untuk cookies F1. Rasa pada cookies F2 (13.23), dan cookies F3 (12.55) kategori netral. Wahidah (2010) menyatakan cita rasa dipengaruhi oleh tiga faktor, yaitu bau, rasa, dan rangsangan mulut (panas dan dingin). Faktor yang pertama dapat dideteksi oleh indera pencium dan dua faktor yang disebutkan terakhir dapat dideteksi oleh sel-sel sensorik pada lidah. Berdasarkan hasil penelitian uji sensoris terhadap rasa / after taste oleh pengamatan panelis pada produk cookies F1, F2, dan F3 menunjukkan bahwa perlakuan penambahan gula palm tidak berpengaruh sangat nyata terhadap rasa / after taste cookies dengan rata-rata uji sensoris untuk cookies F1,F2, dan F3 adalah 3.

Atribut warna pada cookies F1 (12.23), cookies F2 (12.08), dan cookies F3 (11.94) kategori netral. Berdasarkan hasil uji sensoris rata-rata uji sensoris F1,F2,dan F3 sebesar 3.45 dan tidak berpengaruh nyata. Perbedaan warna disebabkan oleh adanya penambahan gula palm yang menyebabkan semakin sedikit gula palm yang ditambahkan, warna cookies semakin berwarna terang (tidak gelap). Panelis lebih menyukai produk dengan warna yang lebih terang, maka tingkat penerimaannya lebih tinggi yang berwarna terang dibandingkan dengan produk yang berwarna lebih gelap dikarenakan adanya reaksi pencoklatan non enzimatis. Winarno (2002) menyatakan bahwa warna merupakan komponen terpenting dalam menentukan kualitas bahan pangan. Suatu bahan pangan yang dinilai tidak baik apabila memiliki warna yang berbeda atau telah menyimpang dari warna yang seharusnya. Penentuan mutu suatu bahan pangan tergantung dari beberapa faktor, tetapi sebelum faktor lain diperhatikan secara visual faktor warna tampil lebih dulu untuk menentukan mutu bahan pangan.

Atribut aroma pada cookies F1 (14.50), cookies F2 (11,04) kategori netral dan cookies F3 (10.05) kategori negatif. Hasil uji sensoris aroma pada cookies F1 sebesar 3.1, hal ini menunjukkan aroma yang Hal 19 Volume 3, Nomor 2, Tahun 2019 
dihasilkan cookies ini berasal dari aroma khas ubi kayu. Secara umum, perlakuan penambahan gula palm sangat mempengaruhi tingkat penerimaan konsumen. semakin tinggi penambahan gula palm, semakin lemah aroma ubi kayu yang tercium, panelis pun makin kurang menyukainya.

Atribut tekstur pada cookies F1 (14.36), cookies F2 (13.06), dan cookies F3 (11.94) kategori netral. Hasil pengujian sensoris terhadap tekstur cookies diperoleh rataan nilai terhadap tekstur produk cookies berkisar antara 3,2 sampai 3.9. Secara deskriptif, hal ini berarti panelis menyatakan suka terhadap produk cookies tersebut. Artinya, semakin tinggi gula palm yang ditambahkan membuat tekstur cookies makin menjadi keras.

Menurut Sutarni et al., (2018) Keadaan konsumen dalam membeli suatu produk sangat dipengaruhi oleh harga produk itu sendiri. Atribut harga pada cookies F1 (13.81), cookies F2 (11.65), dan cookies F3 (10.48) kategori netral. Harga cookies F1 Rp.7500, cookies F2 Rp.9000, dan cookies F3 Rp.10500. Penetapan harga didalam bauran pemasaran sangat penting, karena berkaitan erat dengan hasil penjualan. Harga cookies F1,F2,dan F3 berbeda, karena kandungan gula palm yang berbeda, semakin banyak kandungan gula palm harga yang ditawarkan semakin mahal.

Atribut kemasan pada cookies F1 (12.20), cookies F2 (12.67), cookies F3 (11.56) kategori netral. Penelitian Amelia (2008) kemasan merupakan salah satu atribut produk yang penting karena selain untuk menjaga agar produk tidak mudah rusak, kemasan yang menarik juga menjadi daya tarik tersendiri bagi konsumen. Pada saat hari raya besar misalnya, selain untuk konsumsi keluarga, konsumen menaruh cookies sebagai hiasan di atas meja sebagai suguhan kepada keluarga atau teman yang berkunjung ke rumah mereka untuk bersilaturahmi. Hal ini juga yang membuat kemasan menjadi penting sebagai daya tarik konsumen.

Berdasarkan hasil nilai sikap responden, dapat diketahui secara keseluruhan bahwa total nilai sikap (Ao) untuk cookies F1sebesar 82.37 poin, cookies F2 sebesar 73.73 poin, cookies F3 sebesar 69.16 poin, dengen demikian secara keseluruhan memiliki sikap yang lebih positif terhadap cookies F1 dibandingkan cookies F2 dan cookies F3. Hal ini dapat terjadi karena panelis menilai secara keseluruhan atribut cookies F1 lebih baik dari pada atribut cookies F2 dan cookies F3.

\section{Analisis Proksimat}

Data analisis proksimat (Tabel 6) cookies berbahan baku tepung ubi kayu tinggi protein formulasi terbaik (F1) meliputi analisis kadar air, kadar abu, kadar protein, kadar lemak, dan kadar serat (AOAC, 2005). Hasil analisis Tabel 6 kadar air dari produk cookies berbahan baku tepung ubi kayu tinggi protein adalah sebesar 2,39\%. Cookies berbahan baku tepung ubi kayu tinggi protein belum memiliki SNI, dan yang paling mendekati dengan produk ini adalah cookies berbahan baku tepung terigu. Menurut SNI kadar air cookies maksimal 4,0\% (b/b). Kadar air produk cookies berbahan baku tepung ubi kayu tinggi protein lebih rendah dari cookies berbahan baku tepung terigu, jadi kadar air pada produk cookies berbahan baku tepung ubi kayu tinggi protein masih berada dalam batas aman.

Kadar abu cookies berbahan baku tepung ubi kayu tinggi protein sebesar 1,32\%. Abu merupakan residu yang tertinggal setelah suatu bahan pangan dibakar hingga bebas karbon. Abu adalah zat anorganik sisa hasil pembakaran suatu bahan organik. Kadar abu yang terkandung dalam bahan pangan menunjukkan jumlah kandungan mineralnya. Semakin besar kadar abu suatu bahan pangan, semakin tinggi pula mineral dalam bahan pangan tersebut.

Tabel 6. Data Hasil Analisis Proksimat Terhadap Cookies Berbahan Baku Tepung Ubi Kayu Tinggi Protein

\begin{tabular}{lccc}
\hline \multirow{2}{*}{ Komponen } & Cookies Control & $\begin{array}{c}\text { Cookies Tepung } \\
\text { Ubi Kayu }\end{array}$ & SNI Cookies \\
\cline { 2 - 4 } & $\boldsymbol{\%}$ bb & \% bb & $\%$ \\
\hline Air & 2.22 & 2.39 & Maks. 4 \\
Abu & 0.70 & 1.32 & Maks. 2 \\
\hline
\end{tabular}

Volume 3, Nomor 2, Tahun 2019 Hal 20 


\begin{tabular}{lccc}
\hline Serat & 2.35 & 9.67 & - \\
Lemak & 21.7 & 27.6 & Min. 18 \\
Protein & 5.14 & 4.11 & Min. 6 \\
Karbohidrat & 70.18 & 64.56 & - \\
\hline
\end{tabular}

Sumber : Data Primer, 2019 (diolah)

Kadar protein pada cookies berbahan baku tepung ubi kayu tinggi protein yang terpilih adalah 4,11 $\%$ sedangkan kadar protein pada SNI sebesar $6.0 \%$. Artinya, protein pada cookies berbahan baku tepung ubi kayu tinggi protein hampir mencapai kadar protein sesuai SNI. Protein adalah sumber asam amino yang mengandung unsur-unsur $\mathrm{C}, \mathrm{H}, \mathrm{O}$, dan $\mathrm{N}$. Perbedaan protein dengan lemak dan karbohidrat terdapat pada kandungan $\mathrm{N}$ yang tidak dimiliki oleh keduanya. Fungsi utama protein adalah untuk membentuk jaringan baru dan mempertahankan jaringan yang telah ada. Protein ikut pula mengatur berbagai proses tubuh dengan membentuk zat- zat pengatur tubuh.

Kadar lemak dalam produk cookies berbahan baku tepung ubi kayu tinggi protein adalah sebesar 27,6 $\%$. Lemak merupakan zat makanan yang penting untuk kesehatan tubuh dan sumber energi yang lebih efektif dibanding dengan karbohidrat dan protein. $1 \mathrm{~g}$ lemak menghasilkan 9 kkal, sedangkan karbohidrat dan protein hanya menghasilkan 4 kkal setiap gramnya (Almatsier, 2004). Hasil analisis kadar serat cookies berbahan baku tepung ubi kayu tinggi protein sebesar 9,67\%. Departement of Nutrition, Ministry of Health and Institute of Health (1999) seperti yang dikutip oleh Anggraini (2007) menyatakan bahwa makanan dapat diklaim sebagai sumber serat pangan apabila mengandung serat pangan sebesar 3-6 gram/100 gram. Serat pangan yang terkandung dalam bahan pangan akan mempengaruhi sifat fisiknya. Secara fisiologis serat pangan didefinisikan sebagai komponen tanaman yang tidak terdegradasi secara enzimatis menjadi sub unit yang dapat diserap lambung dan usus halus (Winarno, 2002). Beberapa jenis pangan telah diketahui dapat dijadikan sebagai sumber serat pangan dalam diet yang terbukti efektif pengaruhnya terhadap kesehatan fungsi fisiologis tubuh

\section{KESIMPULAN}

Berdasarkan hasil penelitian konsumen lebih menyukai produk cookies F1 dangan gula palm 25\% bernilai positif, secara keseluruhan nilai ini berarti sikap konsumen terhada produk cookies F1 dinilai baik. Atribut penambahan gula palm 25\% (F1) yaitu rasa dinilai positif. Atribut yang mendapatkan nilai paling besar adalah atribut rasa diikuti oleh atribut aroma, tekstur, harga, warna, dan kemasan. Berdasarkan hasil analisis proksimat cookies berbahan baku tepung ubi kayu tinggi protein perlakuan dengan penambahan gula palm sebesar $25 \%$ Penambahan gula palm sebanyak $25 \%$ memiliki kadar air 3,39\%, kadar protein 27,6\%, kadar lemak, kadar serat 9,67, kadar abu 1,32\% dan kadar karbohidrat 64,56\%

\section{DAFTAR PUSTAKA}

Ade yulya b (2017) analisis proses keputusan pembelian produk nutritional shake herbalife di lima rumah nutrisi di kota jambi, institut pertanian bogor.

Almatsier, S. (2004) Prinsip Dasar Ilmu Gizi. Jakarta: Gramedia Pustaka Utama.

AOAC (2005) 'Of fi cial Methods of Anal y sis of AOAC IN TER NA TIONAL', (February), pp. 1-96. 
Asosiasi Produsen Tepung Terigu Indonesia (2016) Indonesia: Wheat Flour Industry Overview. Indonesia. Available at: http://aptindo.or.id/overview.

[BPS] Badan Pusat Statistik. STATISTIK INDONESIA 2018. Indonesia.

Christina Esti Susanti (2008) 'Upaya Peningkatan Strategi Marketing Mix Pangan Berbasis Bahan Lokal Melalui Analisis Sikap Konsumen Dengan Model Fishbein Di Surabaya', Jurnal Manajemen Pemasaran, $3, \quad$ pp. 1-7. Available at: http://puslit2.petra.ac.id/ejournal/index.php/mar/article/view/18075.

Hanifa, R. , A. Hintono, dan Y. B. P. (2013) 'Kadar Protein, Kadar Kalsium, Dan Kesukaan Terhadap Cita Rasa Chicken Nugget Hasil Substitusi Terigu Dengan Mocaf Dan Penambahan Tepung Tulang Rawan Protein Total , Calcium, and Likes To Taste of Chicken Nugget From the Substitution Wheat Flour With ', Jurnal Pangan dan gizi, 04(08).

Hartono, B., Ningsih, U. W. and Septiarini, N. F. (2012) 'Perilaku Konsumen Dalam Pembelian Bakso Di Malang', Buletin Peternakan, 35(2), p. 137. doi: 10.21059/buletinpeternak.v35i2.600.

Hidayat, B., Muslihudin, M. and Akmal, S. (2018) 'Perubahan Karakteristik Fisikokimia Tepung Onggok Selama Proses Fermentasi Semi Padat Menggunakan Saccharomyces cerevisiae Changes in Physicochemical Characteristics of Cassava Bagasse Flour During Semi-Solid Fermentation Process Using Saccharomyces cerev', 18(3), pp. 146-152.

Kementerian Pertanian (2018) Statistik Konsumsi Pangan. Indonesia.

Nafisah, S. N. U. R. (2013) Sikap Dan Persepsi Konsumen Terhadap Jeruk Lokal Dan Jeruk Impor Di Pasar Modern Kota Bogor.

Ratih Woro Anggraini (2007) Resistant Starch Tipe Iii Dan Tipe Iv Pati Ganyong (Canna Edulis), Kentang (Solanum Tuberosum), Dan Kimpul (Xanthosoma violaceum Schott) SEBAGAI PREBIOTIK, Carbohydrates as Organic Raw Materials III. Institut Pertanian Bogor. doi: 10.1002/9783527614899.ch11.

Rizki Amelia (2008) Perilaku konsumen cookies cokelat 'waroeng cokelat' di kota bogor. Institut Pertanian Bogor.

Sutarni et al. (2018) 'Proses Pengambilan Keputusan', Journal of Food System and Agribusiness, 2(1), pp. 17-24. doi: 10.31227/osf.io/4byj6.

Ujang Sumarwan, Aldi Noviandi, K. (2013) '023 2000 UJANG SUMARWAN ATTITUDES MULTIATRIBUTE FISHBEIN SANDWICH.pdf', 22, pp. 333-334.

Wahidah, N. (2010) 'Komponen - Komponen yang Memengaruhi Cita Rasa Bahan Pangan'. Available at: http://www.idazweek.co.cc/2010/0 2/komponen-komponenyangmemengaruhi- cita.html.

Winarno, F. . (2002) Kimia Pangan dan Gizi. Jakarta: Gramedia. 